\title{
Aquatic Insects Biodiversity and Water Quality Parameters of Receiving Water body
}

\author{
AMPON PAYAKKA andTAENG-ON PROMMI* \\ ${ }^{1}$ Faculty of Liberal Arts and Science, Kasetsart University, \\ Kamphaeng Saen Campus, Nakhon Pathom Province, 73140 Thailand.
}

http://dx.doi.org/10.12944/CWE.9.1.08

(Received: November 30, 2013; Accepted: January 10, 2013)

\begin{abstract}
Biodiversity of aquatic insect and physicochemical water quality parameters in receiving water bodies in Kasetsart University, Kamphaeng Saen Campus, Nakhon Pathom Province, central Thailand were assessed during October 2010 to September 2011. Seven sampling stations, each $100 \mathrm{~m}$ long, were established. Three replicates of samplings by aquatic D-net were used at sampling sites. A total of 4,257 individual of aquatic insect were collected during one year. Six Orders and 12 families were recorded in this study. The family Hydropsychidae and Chironomidae were the most abundance of aquatic insects that found in receiving water bodies. The CCA revealed the family Mesoveliidae and Chironomidae were correlated with alkalinity in receiving water bodies, whereas dissolved oxygen was correlated with family Baetidae, Coenagrionidae, Hydrophilidae, and Helotrephidae. Signs of increasing water quality deterioration were evident in the result of the physicochemical analyses.
\end{abstract}

Key words: Aquatic insects, Biodiversity and Water quality.

\section{INTRODUCTION}

Water is one of man's most important natural resources. Most living organisms in this biosphere can not survive for long periods without water. As the amount of freshwater on the earth is limited, the importance of surface water quality assessment should be considered. Because of a concern for human health and the habitat of aquatic life, global awareness in the maintenance of a clean water world, many people have come to realize the importance of clean surface water to a nation's economy. Most inland freshwater ecosystems are being increasingly polluted by run-off from agricultural fields, degraded land, and disposal of domestic sewage and industrial effluents.

Freshwater aquatic insects inhabit river and stream beds, lakes and reservoirs and are associated with various types of substrates such as mineral sediments, detritus, macrophytes and filamentous algae 1 . They are essential elements in lentic and lotic trophic webs, participating in the energy flow and nutrient cycling ${ }^{2}$. They are also important food resources for fish $^{3}$ and some insectivorous birds ${ }^{5}$. The distribution of aquatic organisms is the result of interactions among their ecological role, the physical conditions that characterize the habitat, and food availability ${ }^{5}$. Thus, the community structure of aquatic insects depends on a number of factors, such as water quality, type of substrate, particle size of sediment, water flow, sediment organic matter availability, oxygen concentration as well as environmental conditions surrounding the water course ${ }^{4,6}$. Because they reflect environmental changes, aquatic insects are often used as indicators of the effects of human activity on water system and provide information on habitat and water quality ${ }^{7}$. The organic enrichment of water caused by both domestic and industrial effluents is a common anthropogenic impact on urban watercourses. This kind of pollution changes physical and chemical characteristics of aquatic systems, thus affecting the assemblage of 
aquatic insects ${ }^{4,8}$. The aim of this study was to investigate the diversity of aquatic insects in relation to water quality variables in order to explore the bioindication potential of aquatic insects for assessing water quality in Kasetsart University, Kamphaeng Saen Campus, central Thailand.

\section{MATERIALS AND METHODS}

\section{Aquatic insects sampling}

Aquatic insects were sampled using aquatic net with a dimension of $30 \times 30 \mathrm{~cm}$ frame, $250 \mu \mathrm{m}$ mesh, $50 \mathrm{~cm}$ length was used throughout the sampling. At each sampling period, triplicate aquatic insect samples were collected. The aquatic net was dragged for a distance of ten meters on the sediment floor and aquatic plants in littoral zone. Samples were placed in white trays for sorting and screening only aquatic insects. Aquatic insects were handpicked from the tray. Any non-aquatic insects caught were immediately returned to the water. The content of each sample (net) was transferred into properly-labelled plastic containers, preserved in $80 \%$ ethanol and taken back to the laboratory for analysis. In the laboratory, aquatic insects were sorted on a Petri dish and identified to the family level using taxonomic keys by several authors ${ }^{9-11}$. Large aquatic insects were sorted by naked eyes whereas the sorting of the smaller ones was done under a dissecting microscope. All the sorted samples were kept in properly-labelled vials containing $80 \%$ ethanol.

\section{Physicochemical water quality parameters}

Samples of water were collected from each sampling period immediately before the sampling of aquatic insects. Three replicates of selected physicochemical water quality parameters were recorded directly at the sampling site and included $\mathrm{pH}$, measured by a $\mathrm{pH}$-meter Waterproof Model Testr30, water temperature was measured by a hand-held thermometer, and dissolved oxygen (DO), which was measured by a $\mathrm{HACH}^{\circledR}$ Model sensION 6 DO meter, total dissolved solid (TDS) and conductivity were measured by a EURECH CyberScan CON110 conductivity/TDS meter. Water samples from each collecting period were stored in polyethylene bottles $(500 \mathrm{~mL})$. The ammonianitrogen $\left(\mathrm{NH}_{4}-\mathrm{N}\right)$, sulfate $\left(\mathrm{SO}_{4}{ }^{2-}\right)$ and nitrate-nitrogen $\left(\mathrm{NO}_{3}-\mathrm{N}\right)$ were determined in accordance with the standard method procedures ${ }^{11}$. Alkalinity was measured by titration ${ }^{11}$.

\section{Data analysis}

Each sampled period total number of family was counted. Canonical correspondence analysis (CCA) of PC-ORD Version $4.0^{13}$ investigate the contribution of the environmental stressors on the distribution and abundance of transformed aquatic insect family data $(\log (x+1))$. The biplot ordination diagram was produced using CanoDraw for Windows 10.

\section{RESULTS AND DISCUSSION}

\section{Aquatic insect composition}

The aquatic insect composition and abundance from the sampled months were summarized in Table 1. Twelve families were identified from a total of 4,257 individuals collected during the sampling period. The main taxonomic groups encountered were Ephemeroptera, Hemiptera, Coleoptera, Trichoptera, Odonata and Diptera. The order Ephemeroptera and Hemiptera had the highest number of family (each 3 families) out of the 12 family found. The highest (9 families) in term of taxa diversity was found in June and was lowest in August, September and April. It was also noticed that the individual of family Hydropsychidae and Chironomidae were found to be highest at all the sampling period. The number of individual of aquatic insect was found to be maximum (627 individuals) in the month of November, which may be due to the presence of riparian vegetation and suitable substrates. The riparian vegetation may provide them protection from predators and suitable environment for the growth of periphytic algae, which is an important food source for many aquatic insects. Most of the aquatic insects utilize plants as a direct food source, sites for oviposition and source of respiratory oxygen ${ }^{12}$. Lowest aquatic insect individuals were found during dry season (March to May), started increasing in June and remained at high levels up to the month of July and dramatically decreased during wet season. Large loads of clay brought into the water bodies by nearby areas during wet season, induced a high sedimentation of fine particles and disturbances of the littoral zone. Increased sediments load in water bodies reduced the transparency, leading to the 
PAYAKKA \& PROMMI., Curr. World Environ., Vol. 9(1), 53-58 (2014)

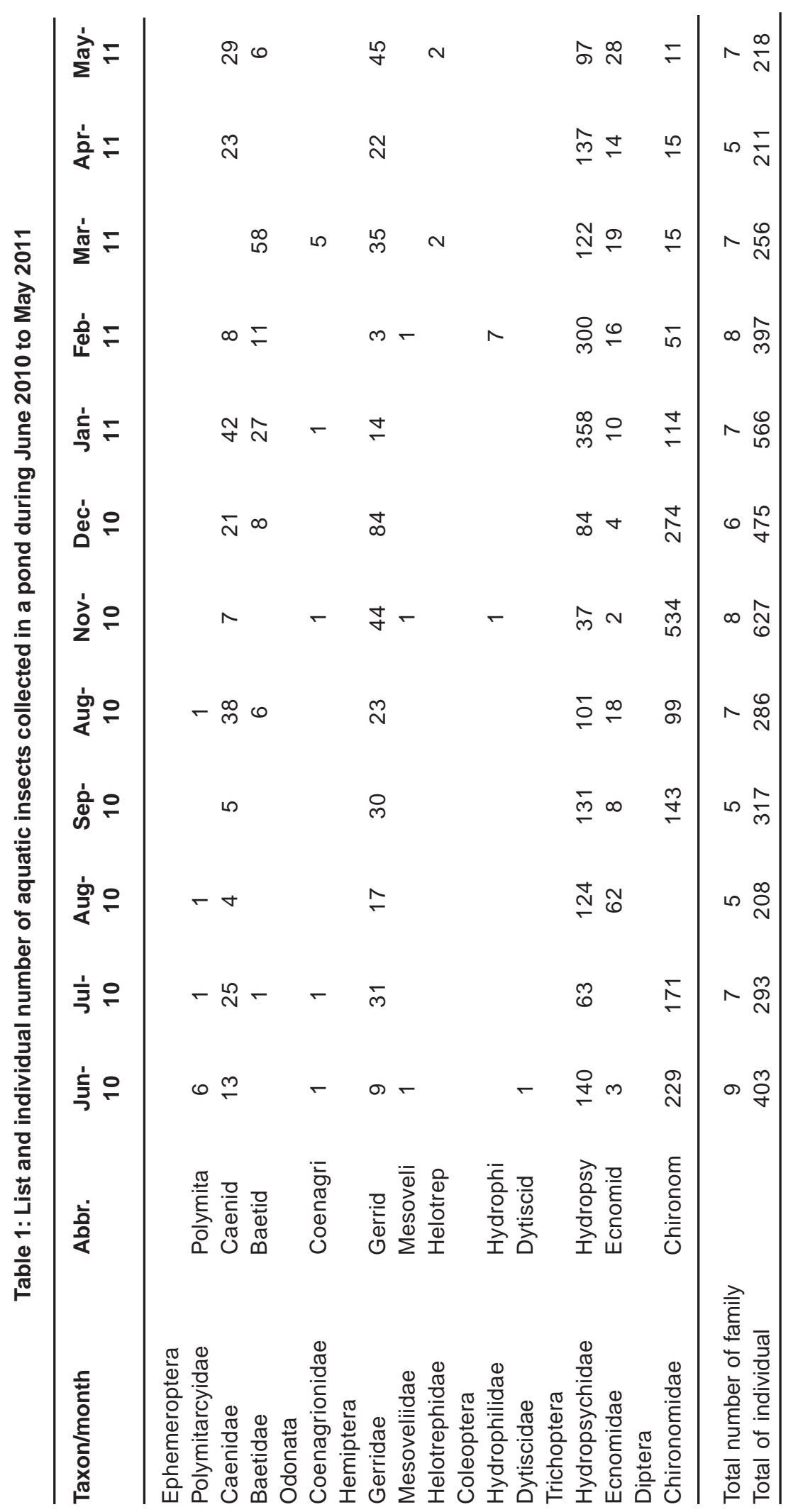


reduction in primary production of the water bodies. During this period, availability of food material for aquatic insect was very sparse, and the littoral zone was submerged. Aquatic insects were adversely affected by the floods, and there was a significant effect of seasonality on taxon richness at all the sampling periods.

\section{Physicochemical water quality parameters}

Mean values of selected physicochemical parameters of water quality during this study are presented in Table 2. Temperature was relatively lower during the wet season than the dry season. This might be attributed to the sampling time. The water temperature was maximum in September $\left(35.1 \mathrm{C}^{\circ}\right)$ and minimum in cool-dry season (December to February) (28.9 Co). The minimum and maximum temperatures $\left(25.0\right.$ and $35.5 \mathrm{C}^{\circ}$ respectively) are normal for tropical waters and required for the normal growth of aquatic organisms. The $\mathrm{pH}$ of water was slightly alkaline in all year round (8.0-8.6). Accumulation of free carbon dioxide

Table 2: Mean physicochemical water quality variables in a pond during June 2010 to May 2011

\begin{tabular}{|c|c|c|c|c|c|c|c|c|c|c|c|}
\hline $\begin{array}{l}\text { Month/ } \\
\text { factors }\end{array}$ & $\begin{array}{l}\text { WT } \\
\left({ }^{\circ} \mathrm{C}\right)\end{array}$ & $\mathrm{pH}$ & $\begin{array}{c}\text { DO } \\
\left(\mathrm{mg} \mathrm{l}^{-1}\right)\end{array}$ & $\begin{array}{c}\text { EC } \\
\text { (is/cm) }\end{array}$ & $\begin{array}{l}\text { TDS } \\
\left(\mathrm{mg} \mathrm{l}^{-1}\right)\end{array}$ & $\begin{array}{l}\text { Turbid } \\
\left(\mathrm{mg} \mathrm{l}^{-1}\right)\end{array}$ & $\begin{array}{l}\text { Alkali } \\
\left(\mathrm{mg} \mathrm{l}^{-1}\right)\end{array}$ & $\begin{array}{l}\mathrm{NH}_{4}-\mathrm{N} \\
\left(\mathrm{mg} \mathrm{l}^{-1}\right)\end{array}$ & $\begin{array}{c}\mathrm{PO}_{3-}^{4} \\
\left(\mathrm{mg} \mathrm{l}^{-1}\right)\end{array}$ & $\begin{array}{l}\mathrm{NO}_{3}-\mathrm{N} \\
\left(\mathrm{mg} \mathrm{l}^{-1}\right)\end{array}$ & $\begin{array}{c}\mathrm{SO}_{4}{ }^{2-} \\
\left(\mathrm{mg} \mathrm{l}^{-1}\right)\end{array}$ \\
\hline Jun-10 & 32.0 & 8.1 & 2.3 & 274.0 & 135.0 & 14.0 & 130.0 & 0.27 & 0.11 & 2.10 & 7.00 \\
\hline Jul-10 & 31.6 & 8.1 & 2.2 & 295.3 & 149.3 & 10.0 & 138.0 & 0.23 & 0.21 & 1.40 & 28.00 \\
\hline Aug-10 & 32.7 & 8.1 & 1.5 & 266.0 & 131.3 & 23.0 & 130.0 & 2.49 & 0.32 & 1.40 & 9.00 \\
\hline Sep-10 & 35.1 & 8.4 & 1.7 & 190.6 & 95.7 & 13.0 & 142.0 & 0.35 & 0.19 & 1.90 & 8.00 \\
\hline Oct-10 & 31.8 & 8.6 & 1.3 & 540.3 & 275.0 & 19.0 & 96.0 & 1.60 & 1.94 & 0.60 & 9.00 \\
\hline Nov-10 & 33.0 & 8.4 & 1.4 & 326.3 & 164.7 & 29.0 & 134.0 & 0.36 & 0.14 & 0.90 & 14.00 \\
\hline Dec-10 & 30.2 & 8.2 & 6.2 & 228.0 & 114.0 & 22.0 & 108.0 & 0.37 & 0.91 & 12.50 & 9.00 \\
\hline Jan-11 & 28.9 & 8.0 & 5.6 & 182.3 & 91.0 & 16.0 & 72.0 & 0.58 & 0.12 & 1.30 & 8.00 \\
\hline Feb-11 & 28.9 & 8.1 & 4.0 & 182.7 & 91. & 10.0 & 82.0 & 0.26 & 0.0 & 1.10 & 2.00 \\
\hline Mar-11 & 28.9 & 8.0 & 5.4 & 410.3 & 199.7 & 2.0 & 44.0 & 0.34 & 0.17 & 1.70 & 4.00 \\
\hline Apr-11 & 31.5 & 8.0 & 19 & 270.0 & 136.7 & 10.0 & 66.0 & 0.34 & 0.30 & 1.20 & 2.00 \\
\hline May-11 & 32.0 & 8.1 & 5.8 & 336.3 & 167.0 & 41.0 & 54.0 & 0.40 & 0.29 & 2.10 & 6.00 \\
\hline
\end{tabular}

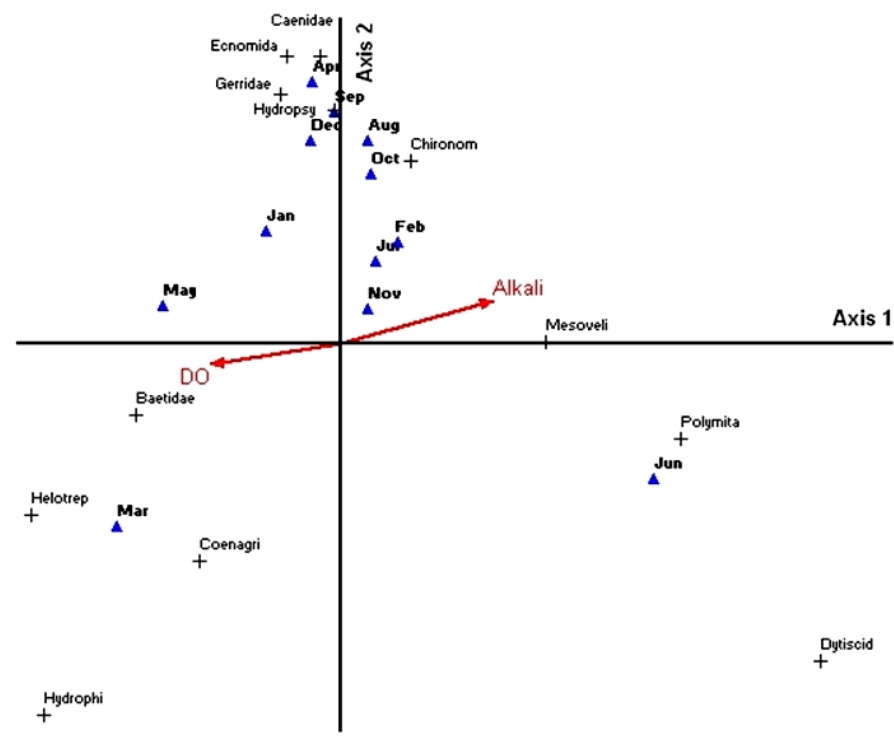

Fig. 1: CCA showing correlation between aquatic insect taxa and physicochemical variables. Abbreviations of taxonomic are shown in Table 1 
due to little photosynthetic activity of phytoplankton causes a lower $\mathrm{pH}$ value of the water while intense photosynthetic activities of phytoplankton will reduce the free carbon dioxide content resulting in increased $\mathrm{pH}$ values ${ }^{14-15}$. Sources of dissolved oxygen in the aquatic environment include the atmosphere and photosynthesis, and depend on its solubility while reduction in oxygen was due to respiration, decay by aerobic bacteria, and decomposition of dead decaying sediments ${ }^{14}$. The dissolved oxygen was maximum $\left(6.2 \mathrm{mg} \mathrm{l}^{-1}\right)$ in November and minimum $\left(1.25 \mathrm{mg} \mathrm{l}^{-1}\right)$ in September. The total dissolved solids and electrical conductivity was maximum $\left(275.0 \mathrm{mg} \mathrm{l}^{-1}, 540.3\right.$ is $\left.\mathrm{cm}^{-1}\right)$ in September and minimum $\left(91.0 \mathrm{mg} \mathrm{l}^{-1}, 182.3\right.$ is cm$\left.{ }^{1}\right)$ in December. The general trend in this study was that conductivity tended to increase in the dry season. Increase in electrical conductivity was due to low precipitation, higher atmospheric temperature resulting in higher evapotranspiration rates and higher total ionic concentration and saline intrusion from underground sources. It could also be due to a high rate of decomposition and mineralisation by microbes and nutrient regeneration from bottom sediments ${ }^{15}$. The mean concentration value of sulfate ranged from 2.0 to $14.0 \mathrm{mg} \mathrm{l}^{-1}$. The mean dissolved nutrients, nitratenitrogen, ammonia-nitrogen and orthrophosphate concentrations varied from 0.6 to $12.5 \mathrm{mg} \mathrm{l}^{-1}$ and 0.23 to $2.49 \mathrm{mg} \mathrm{l}^{-1}$ and 0.09 to $1.94 \mathrm{mg} \mathrm{l}^{-1}$, respectively. The mean alkalinity values ranged from 44 to $142 \mathrm{mg} \mathrm{l}^{-1}$.

\section{Correlations of aquatic insect taxa and water quality parameters}

Twelve taxa were selected in the CCA (Figure 1). Alkalinity was positively correlated with Mesoveliidae and Chironomidae, whereas dissolved oxygen was negatively correlated with
Baetidae, Coenagrionidae, Hydrophilidae, and Helotrephidae. The results from CCA indicated the low diversity was probably due to higher alkalinity and lower dissolved oxygen in the month of the rainy season. In streams, biological condition is strongly influenced by water chemistry and habitat quality. The combination of water analysis, diversity indices and water quality indices were satisfactorily applied to investigate the river health ${ }^{17}$. Low dissolved oxygen, high nitrate or phosphorous concentrations, and low pH can cause reduced water quality. Good habitat quality is generally characterized by a heterogeneous habitat with both slow and fast moving water, woody debris, substrate variety, and well-vegetated, stable banks. Impairment of habitat and water chemistry can lead to reduce the diversity of aquatic macroinvertebrates ${ }^{18}$.

\section{CONCLUSIONS}

The abundance of aquatic insect was higher during the period of rains and reduced during the dry period. The results obtained by the CCA suggest that alkalinity and dissolved oxygen are highly correlated with the aquatic insect assemblages. To get a better understanding of relationships between aquatic insect assemblages and environmental variables, further study is needed to increase the sampling frequencies and periods and to examine more water quality parameters.

\section{ACKNOWLEDGEMENT}

This study was funded by the Graduate School Kasetsart University year 2012 and Faculty of Liberal Arts and Science for Ampon Payakka.

\section{REFERENCES}

1. Rosenberg D.M. and Resh V. H., Freshwater Bio monitoring and Benthic Macro invertebrates, Chapman and Hall, New York, (1993).

2. Whiles M.R. and Wallace J.B., Leaf litter decomposition and macroinvertebrate communities in headwater streams draining pine and hardwood catchments.
Hydrobiologia 353(1-3), 107-119 (1997).

3. Wallace J.B. and Webster J.R., The role of macroinvertebrates in stream ecosystem function. Annual Review of Entomology; 41: 115-139 (1996).

4. Ward D., Holmes N. and JOSÉ P., The New Rivers and Wildlife Handbook. Bedfordshire: RSPB, NRA, The Wildlife Trusts (1995). 
5. Merritt R.W. and Cummin K.W., An introduction to the aquatic insects of North America. 3rd ed. Kendall/Hunt Publishing Company (1996).

6. $\quad$ Buss D.F., Baptista D.F., Nessimain J.L. and Egler M., Substrate specificity, environmental degradation and disturbance structuring macroinvertebrate assemblages in neotropical streams. Hydrobiologia 518(13): 179-188 (2004).

7. Woodcock T.S. and Huryn A., The response of macroinvertebrate production to a pollution gradient in a headwater stream. Freshwater Biology; 52(1): 77-196 (2007).

8. Hynes H.B.N., The ecology of running waters. Canada: University of Toronto Press (1970).

9. Wiggins G.B., Larvae of the North American Caddisfly Genera (Trichoptera). 2 ${ }^{\text {nd }}$ edition. University of Toronto Press (1996).

10. Dudgeon D., Tropical Asian stream: Zoobenthos, ecology and conservation. Hong Kong University Press. Hong Kong (1999).

11. Yule C.M. and Sen Y.H., Freshwater Invertebrates of the Malaysian Region. Aura Productions Sdn. Bhd. Selangor, Malaysia (2004).

12. APHA, AWWA, WPCF, Standard method for the examination of water and wastewater. $18^{\text {th }}$ ed. American Public Health Association.
Washington DC (1992).

13. McCune B. and Mefford M.J., PC-ORD. Multivariate analysis of ecological data, version 4. MjM Software Design, Gleneden Beach, Oregon (1999).

14. Gupta S.K. and Gupta R.C., General and Applied Ichthyology (Fish and Fisheries) S. Chand and Company Ltd. Ram Nagar, New Delhi (2006).

15. Egborge A.B.M., Water Pollution in Nigeria; Biodiversity and Chemistry of Warri River", Vol. 1 Ben Miller Books Nigeria Limited (1994).

16. Shama R.C. and Rawat J.S., Monitoring of aquatic macroinvertebrates as bioindicator for assessing the health of wetland: A case study in the Central Himalayas, India, Ecological Indicator, 9: 118-128 (2009).

17. Salman A.A., Che Salmah M.R., Abu Hassan A., Suhaila A.H. and Siti Azizah M.N., Influence of Agricultural, Industrial, and Anthropogenic Stresses on the Distribution and Diversity of Macroinvertebrates in Juru River Basin, Penang, Malaysia., Ecotoxicology and Environmental Safety; 74(5): 1195-1202 (2011).

18. Resh V. and Betts E., Bioindicators of Strawberry Creek, Department of Integrative Biology, University of California (2007). 